\title{
LOW BONE MINERAL DENSITY IN
} NONCHOLESTATIC LIVER CIRRHOSIS:

\section{prevalence, severity and prediction}

\author{
Fátima Aparecida Ferreira FIGUEIREDO ${ }^{1}$, Cynthia BRANDÃ ${ }^{2}$, \\ Renata de Mello PEREZ ${ }^{3}$, Walnei Fernandes BARBOSA ${ }^{3}$ and \\ Mario KONDO ${ }^{3}$
}

\begin{abstract}
Background - Metabolic bone disease has long been associated with cholestatic disorders. However, data in noncholestatic cirrhosis are relatively scant. Aims - To determine prevalence and severity of low bone mineral density in noncholestatic cirrhosis and to investigate whether age, gender, etiology, severity of underlying liver disease, and/or laboratory tests are predictive of the diagnosis. Patients/Methods - Between March and September/1998, 89 patients with noncholestatic cirrhosis and 20 healthy controls were enrolled in a cross-sectional study. All subjects underwent standard laboratory tests and bone densitometry at lumbar spine and femoral neck by dual X-ray absorptiometry. Results - Bone mass was significantly reduced at both sites in patients compared to controls. The prevalence of low bone mineral density in noncholestatic cirrhosis, defined by the World Health Organization criteria, was $78 \%$ at lumbar spine and $71 \%$ at femoral neck. Bone density significantly decreased with age at both sites, especially in patients older than 50 years. Bone density was significantly lower in post-menopausal women patients compared to pre-menopausal and men at both sites. There was no significant difference in bone mineral density among noncholestatic etiologies. Lumbar spine bone density significantly decreased with the progression of liver dysfunction. No biochemical variable was significantly associated with low bone mineral density. Conclusions - Low bone mineral density is highly prevalent in patients with noncholestatic cirrhosis. Older patients, post-menopausal women and patients with severe hepatic dysfunction experienced more advanced bone disease. The laboratory tests routinely determined in patients with liver disease did not reliably predict low bone mineral density.
\end{abstract}

HEADINGS - Bone density. Bone diseases, metabolic. Osteoporosis. Liver cirrhosis.

\section{INTRODUCTION}

Metabolic bone disease has long been recognized as an important complication of chronic liver diseases, particularly in cholestatic disorders ${ }^{(1,10,15,16,17,20,36)}$. It is associated with pathological fractures, attenuated quality of life, and increased mortality $^{(3,14)}$. In patients submitted to a liver transplantation, an additional acute loss of bone mass occurs in the early postoperative period and it is associated with an increased risk of fractures, especially in patients with pre-existing bone disorders ${ }^{(18,34)}$. The metabolic bone disease that often occurs in individuals with chronic liver disease has also been called hepatic osteodystrophy ${ }^{(19)}$. Conceptually, it can be divided into osteomalacia, disorder defined by a defective mineralization of newly formed osteoid, and osteoporosis, disorder characterized by bone tissue that is fully mineralized but deficient in mass ${ }^{(22)}$. Although early reports proposed that the bone disease associated with liver diseases was related to vitamin D deficiency or diminished exposure to ultraviolet sunlight ${ }^{(4,36)}$, osteoporosis was recently seen to be the most common abnormality found ${ }^{(3,8,17,37)}$. Traditionally it can be evaluated throughout bone biopsies or $\mathrm{x}$-ray. However, the first method is too invasive and the second not reliable to trabecular bone, the most common site of pathological fractures. The development of dual energy x-ray absorptiometry (DEXA) has facilitated the accurate determination of bone mineral density (BMD) with low doses of radiation ${ }^{(6,29)}$. Low BMD is a strong predictor for subsequent fracture ${ }^{(25)}$.

This study was partially supported by grants from CAPES and Fulbright Commission (UERJ/UNIFESP).

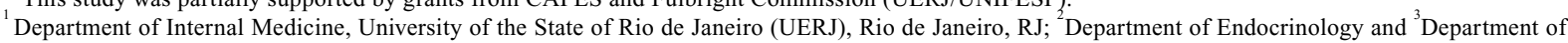
Gastroenterology, "Escola Paulista de Medicina", Federal University of São Paulo (UNIFESP), SP, Brazil.

Address for correspondence: Dr. Fátima Aparecida Ferreira Figueiredo - Disciplina de Gastroenterologia - Universidade Estadual do Rio de Janeiro - Rua Araújo Lima, 24 / 201 - 20541-050 - Rio de Janeiro, RJ, Brazil. E-mail: faff@gbl.com.br 
The prevalence and presentation of bone disease in noncholestatic chronic liver disease have been poorly described when compared with cholestatic liver disease ${ }^{(5,9,28,38)}$.

The aims of this study were to determine the prevalence and severity of low BMD in patients with noncholestatic liver cirrhosis (NCC) and to investigate whether age, gender, etiology, severity of underlying liver disease, and/or laboratory tests are predictive of the diagnosis.

\section{MATERIAL AND METHODS}

\section{Subjects}

Between March and September, 1998, a total of 92 consecutive patients with liver cirrhosis attending the Liver Unit of "Escola Paulista de Medicina”, Federal University of São Paulo, SP, Brazil, were enrolled in a cross-sectional study. Twenty healthy volunteers without liver diseases served as controls. All subjects underwent standard laboratory tests and bone densitometry by DEXA. Written informed consent was obtained from all participants and the study was approved by the institution's ethics committee.

The diagnosis of cirrhosis was based on laparoscopy and histological examination or on clinical and laboratory findings when coagulation parameters did not allow liver biopsy. Clinical and laboratory findings included signs of portal hypertension and hepatic insufficiency. NCC was defined as cirrhosis in the absence of any histopathological, serological and biochemical markers of primary biliary cirrhosis or primary sclerosing cholangitis (PSC) and in the absence of rising in alkaline phosphatase above three times normal. None of the subjects had a history of clinical conditions or signs related to deranged bone metabolism. At the time of the study, no one had symptomatic fractures. Subjects taking vitamin D, estrogens, corticosteroids or calcium supplements and patients with cholestatic liver cirrhosis were excluded from this study.

\section{Bone densitometry}

BMD of the second to fourth lumbar vertebrae (lumbar spine) and femoral neck with an antero-posterior projection were determined by DEXA (Hologic QDR 4500A) following the procedures proposed by the manufacturer. BMD was expressed as grams per square centimeter, T-score and Z-score. The World Health Organization (WHO) criteria for osteopenia and osteoporosis were used to define low $\mathrm{BMD}^{(24)}$. The WHO has operationally defined osteopenia as a BMD between -1 and -2.5 standard deviation (SD) and osteoporosis as a BMD below $-2.5 \mathrm{SD}$ the mean peak value in young adults (Tscore $)^{(24)}$. BMD was also compared to the mean value in normal subjects of the same age, sex, and ethnic group (Z-score). A Z-score below -1SD corresponds to a value in the lowest 25 percentile of the reference range, a value at which the risk of fractures is approximately doubled.

\section{Laboratory determinations}

After an overnight fast a sample of venous blood was withdrawn for measurement of blood tests through standard techniques. These included hemoglobin, lymphocytes, alkaline phosphatase, gamma glutamiltranspeptidase, total bilirubin, aspartate amino transferase, alanine amino transferase, prothrombin index, albumin, glucose, urea, creatinine, sodium, potassium, calcium, phosphate, magnesium, cholesterol and triglycerides. The calcium level was corrected according to albumin level, raising the total calcium $0.8 \mathrm{mg} / \mathrm{dL}$ for each $1 \mathrm{~g} / \mathrm{dL}$ decrease in serum albumin below $4.0 \mathrm{~g} / \mathrm{dL}^{(11)}$.

\section{Statistical analysis}

All data were recorded in a database system using a personal computer, and statistical analyses were performed using SPSS system for Windows (version 8.0). The results were expressed as means \pm SD. Correlation of BMD in different sites was obtained by Spearman's rank correlation. Univariate statistical analysis was performed by means of the chi-square test for categorical variables and a two-tail $t$-test for independent samples for continuous variables. Differences among more than two groups were assessed by one-way analysis of variance (ANOVA). Logistic regression analysis was performed to identify independent risk factors, being low BMD the dependent variable. Values of $P \leq 0.05$ were considered significant.

\section{RESULTS}

Three patients with diagnosis of PSC were excluded and the patient group was composed for 89 subjects. Fifty-five (62\%) patients were men and the mean age was $52 \pm 11$ years (range: 19-70 years). Twenty-three $(72 \%)$ of the female patients were post-menopausal. Forty-six (52\%) patients had an alcoholic etiology for liver disease and 43 (48\%) had nonalcoholic etiology (19 viral, 3 autoimmune, 6 nonalcoholic steatohepatitis, 1 hemochromatosis, and 14 cryptogenic cirrhosis). The control group was composed of 12 (60\%) females and the mean age was $45 \pm 15$ years (range: $20-79$ years). A summary description of the demographic, clinical and biochemical data is shown in Table 1. All patients were classified according to the Child-Pugh score $^{(35)}$ as follows: Child A (32 pt, 36\%), Child B (34 pt, 38\%) and Child C (23 pt, 26\%). Serum calcium levels, but not corrected calcium levels, were lower in Child $\mathrm{C}$ patients compared to Child A and B and controls. 
TABLE 1 - Distribution of demographic, clinical and laboratory data in the study population

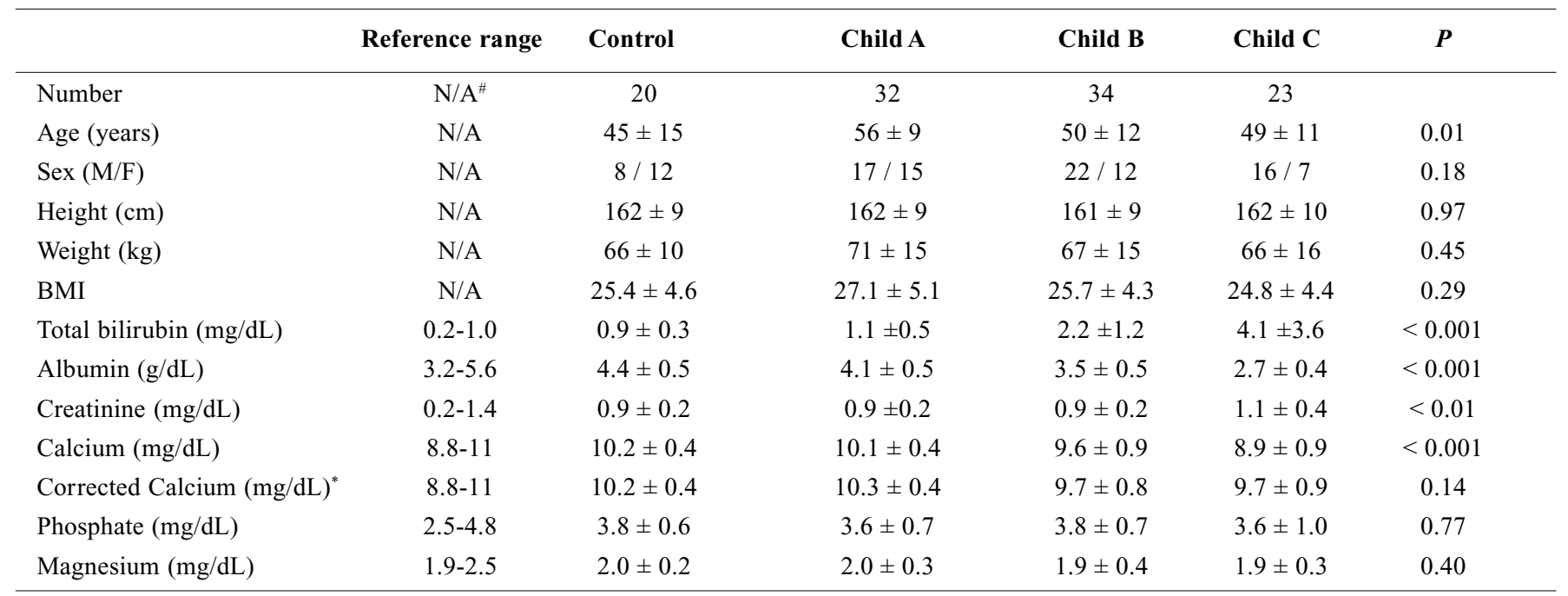

Notes: All data are expressed as mean \pm SD. ${ }^{~ N} / A-$ not applicable ${ }^{*}$ Corrected to serum albumin level of $4 \mathrm{~g} / \mathrm{dL}$

TABLE 2 - DEXA data in the study population

\begin{tabular}{lcccccc}
\hline & & Lumbar spine & & \multicolumn{2}{c}{ Femoral neck } \\
& BMD $\left(\mathbf{g} / \mathbf{c m}^{2}\right)$ & T-score & Z-score & BMD $\left(\mathbf{g} / \mathbf{c m}^{2}\right)$ & T-score & Z-score \\
\hline Controls & $0.98 \pm 0.13$ & $-1.0 \pm 0.3$ & $-0.41 \pm 0.3$ & $0.84 \pm 0.11$ & $-0.8 \pm 0.2$ & $0.14 \pm 0.01$ \\
Patients & $0.89 \pm 0.17$ & $-1.9 \pm 0.2$ & $-1.25 \pm 0.2$ & $0.78 \pm 0.14$ & $-1.6 \pm 0.1$ & $-0.3 \pm 0.01$ \\
$P$ value & $<0.01$ & $<0.01$ & $<0.01$ & 0.05 & $<0.01$ & 0.09 \\
\hline
\end{tabular}

Notes: All data are expressed as mean \pm SD. $P$ value calculated by two-tail $t$ test for independent samples

TABLE 3 - Distribution of BMD* according to age range

\begin{tabular}{lcccccc}
\hline & \multicolumn{1}{c}{ Lumbar spine } & & & \multicolumn{2}{c}{ Femoral neck } \\
& $\mathbf{5 0 \text { years }}$ & $>\mathbf{5 0}$ years & $\boldsymbol{P}$ value & $\mathbf{5 5 0 \text { years }}$ & $\boldsymbol{> 5 0}$ years & $\boldsymbol{P}$ value \\
\hline Controls & $1.0 \pm 0.12$ & $0.95 \pm 0.13$ & 0.45 & $0.86 \pm 0.13$ & $0.82 \pm 0.11$ & 0.57 \\
Patients & $0.93 \pm 0.13$ & $0.85 \pm 0.20$ & 0.03 & $0.82 \pm 0.14$ & $0.75 \pm 0.14$ \\
$\boldsymbol{P}$ value & 0.04 & $<0.01$ & & 0.36 & 0.01 \\
\hline
\end{tabular}

Notes: *BMD bone mineral density

All data are expressed as mean $\pm \mathrm{SD}$

$P$ value calculated by two-tail $t$ test for independent samples

TABLE 4 - Distribution of BMD* according to sex

\begin{tabular}{lcccccccc}
\hline & \multicolumn{4}{c}{ Lumbar spine } & & \multicolumn{2}{c}{ Femoral neck } \\
& Male & Pre-meno female & Post-meno female & ANOVA & Male & \multicolumn{2}{c}{ Pre-meno female Post-meno female ANOVA } \\
\hline Controls & $0.99 \pm 0.12$ & $1.07 \pm 0.11$ & $0.95 \pm 0.12$ & 0.13 & $0.84 \pm 0.15$ & $0.90 \pm 0.1$ & $0.82 \pm 0.11$ & 0.53 \\
Patients & $0.93 \pm 0.17$ & $0.88 \pm 0.12$ & $0.82 \pm 0.19$ & 0.03 & $0.81 \pm 0.15$ & $0.78 \pm 0.14$ & $0.70 \pm 0.1$ & $<0.01$ \\
$P$ value & 0.27 & $<0.01$ & 0.01 & & 0.71 & 0.08 & $<0.01$ \\
\hline
\end{tabular}

Notes: All data are expressed as mean \pm SD

$* \mathrm{BMD}=$ bone mineral density

$P$ value calculated by two-tail $t$ test for independent samples or by ANOVA as appropriate 




FIGURE 1 - Prevalence of osteopenic bone disease in noncholestatic cirrhosis. The patients presented higher prevalence and greater severity than controls in both sites

The correlation coefficient of lumbar spine BMD with femoral neck BMD was $0.633, P<0.001$. Bone mass was significantly reduced at both sites studied in patients with NCC compared to controls independently of the used criteria (Table 2). According to the WHO criteria, the prevalence of low bone density in patients with NCC was $77.5 \%$ at the lumbar spine and $70.8 \%$ at the femoral neck (Figure 1). Thirty-four (38.2\%) patients met criteria for osteoporosis and 35 (39.3\%) met criteria for osteopenia at the lumbar spine site. Nineteen (21.3\%) patients met criteria for osteoporosis and 44 (49.4\%) met criteria for osteopenia at the femoral neck site. Fifty-nine $(66.3 \%)$ patients showed Z-score below -1SD at the lumbar spine site and 23 $(25.8 \%)$ at the femoral neck site. No one healthy control met criteria for osteoporosis. Seven (32\%) controls met criteria for osteopenia at the lumbar spine site and nine (41\%) at the femoral neck site.

BMD was correlated with the three major risk factors: age, gender, and severity of liver disease. There was a significant negative correlation between age and BMD at the lumbar spine $(\mathrm{r}=-0.23, P=0.03)$ and femoral neck $(\mathrm{r}=-0.29, P<0.001)$. BMD significantly decreased with age in patients with NCC at more than the normal rate of decline (Table 3). The mean BMD was significantly lower in patients older when compared to younger than 50 years at the lumbar spine $(P=$ $0.03)$ and femoral neck $(P=0.02)$. In the same age range, patients had significantly lower BMD compared to healthy controls at the lumbar spine. Differences in BMD values between patients and healthy controls were significant for the group older than 50 years at the femoral neck, but not for the group younger than 50 years.

The mean BMD was significantly lower in post-menopausal female patients when compared to pre-menopausal female and male patients in both lumbar spine $(P=0.03)$ and femoral neck $(P<0.01)$ (Table 4). In patients, there was a greater decrease in BMD than in

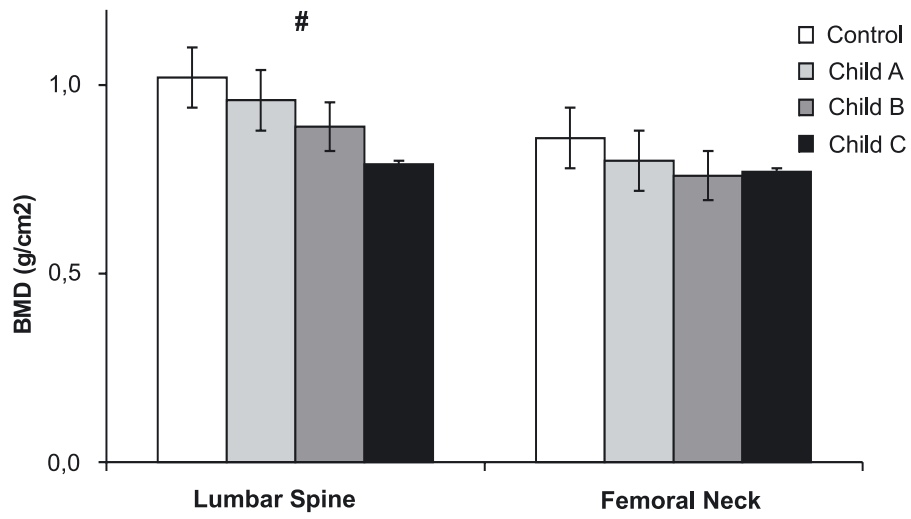

FIGURE 2 - Distribution of BMD expressed as $\mathrm{g} / \mathrm{cm}^{2}$ among the healthy controls and Child's classification. $\# P \leq 0.001$ BMD decreased as the liver disease progressed mainly in lumbar spine site

healthy controls. Differences in BMD between men with cirrhosis and healthy men were not significant. However, in women with cirrhosis, the mean BMD was lower than in healthy controls in both pre- and post-menopausal status.

There was no variation in BMD values with the etiologies of noncholestatic liver disease. The mean BMD was $0.91 \pm 0.14$ in alcoholic patients and $0.87 \pm 0.16$ in nonalcoholic patients at the lumbar spine $(\mathrm{P}=0.25)$. The mean $\mathrm{BMD}$ was $0.80 \pm 0.15$ in alcoholic patients and $0.76 \pm 0.14$ in nonalcoholic patients at the femoral neck $(P=0.28)$.

The mean BMD decreased significantly with the progression of the liver dysfunction, as measured by Child-Pugh score, at the lumbar spine $(P<0.001)$ (Figure 2$)$. It was not significant at the femoral neck $(P=0.10)$, although BMD levels were low in all stages of cirrhosis. At the lumbar spine, the mean BMD was $1.02 \pm 0.11$, $0.96 \pm 0.18,0.89 \pm 0.13$ and $0.79 \pm 0.19$ in controls and Child's classification A, B and C, respectively. At the femoral neck, the mean $\mathrm{BMD}$ was $0.86 \pm 0.12,0.80 \pm 0.15,0.76 \pm 0.13$ and $0.77 \pm 0.16$ in controls and Child's classification A, B and C, respectively.

The lowest BMD was seen in females, aged more than 50 years and Child's class C.

No strong correlation was found among BMD and laboratory values. The only biochemical parameter significantly correlated with BMD was albumin $(r=0.24, P=0.04)$. In the logistic regression, no biochemical variable was significantly associated with low BMD.

\section{DISCUSSION}

With the improvement in survival of patients with chronic liver disease and with the development of liver transplantation, the clinical 
significance of hepatic osteodystrophy has increased. However, in many patients with noncholestatic liver disease, it still remains unrecognized and untreated. In this study we found that low BMD is highly prevalent in patients with noncholestatic cirrhosis. Advanced age, post-menopausal female status and severe liver dysfunction were associated with higher prevalence of low BMD. No standard laboratory measurement could predict the diagnosis. It is a silent condition and BMD, measured by bone densitometry, remains the only appropriate test for its diagnosis.

Although metabolic bone disease has been well described in patients with cholestatic liver diseases ${ }^{(1,17)}$, we found that the prevalence is also high among patients with noncholestatic etiologies. The prevalence rates of low BMD were twice as high among patients than in controls. It was also of greater severity in patients than in controls. Using the WHO criteria, almost $80 \%$ of patients with $\mathrm{NCC}$ had low BMD at both sites. However, the rate can vary with the site and the criteria used to define it. Using Z-score, the prevalence rates varied widely between the sites. Twenty-six percent to $66 \%$ of patients had BMD lower than age and gender-matched subjects (Z-score). The frequency of low BMD in our study was higher than that reported in others series ${ }^{(1,3,6,30)}$. It can be partially explained because of the heterogeneity of definitions, since those studies used Z-score instead of T-score to diagnosis metabolic bone disease. As age is recognized as an independent risk factor for low BMD, the use of other criteria rather than T-score can underestimate its prevalence.

Although metabolic bone disease is a systemic condition, BMD assessments at one site correlated imperfectly with measurements at other sites. Other authors also reported that correlation indices at many sites can vary from 0.4 to $0.9^{(3)}$. Screening for low BMD with single site measurements can underestimate its frequency and severity and is not a perfect predictor of BMD at any other site ${ }^{(23)}$. Due to the faster rate of renewal in trabecular bone than in cortical bone (up to 8 times), sites with a high proportion of trabecular bone such as vertebrae and hips will be affected earliest ${ }^{(39)}$. Since vertebrae consist of $50 \%$ trabecular bone and femoral neck consists of $30 \%$ trabecular bone, these alterations will be apparent earlier and more intense at the lumbar spine than femoral neck site, explaining the differences found between these sites ${ }^{(39)}$.

No single set of risk factors for low BMD has been consistently identified. The most important risk factors fall into four major categories: age, gender, environmental (alcohol, calcium) and association with chronic diseases. ANGULO et al. ${ }^{(1)}$ reported that age was the only variable inversely correlated with lumbar spine BMD in cholestatic liver diseases. In both sites, patients with NCC older than 50 years had lower BMD. Peak adult bone mass is achieved early in life, with a gradual, progressive decline in BMD beginning at about age 40 to 45 years ${ }^{(25)}$. According to TSUNEOKA et al. ${ }^{(38)}$, BMD tended to decrease with age in patients with cirrhosis at a rate similar to healthy controls. However, in our study, we noted that the normal age-related changes in bone density become more pronounced in patients with liver cirrhosis causing a marked weakening of the bones. NCC seems to accelerate the process of losing bone mass associated to age. Possible explanations for this include the physical inactivity or the early hormonal alterations present in liver cirrhosis ${ }^{(2,}$ $7,12,13,16,33,40)$

We found significantly lower BMD in post-menopausal female patients compared to male and pre-menopausal patients and to controls. They had less mass per unit of bone volume at both sites. Osteoporosis develops earlier in women who have lost ovarian function. Since we had $72 \%$ of female patients in post-menopausal period, the reason for this gender-specific difference can partially be explained by the differences in the aging pattern ${ }^{(25)}$. However, the difference between patient and control women corroborates the idea that NCC also accelerates the process of losing bone mass associated to female gender. Our study is in agreement with the findings of MASAKI et al. ${ }^{(28)}$ that showed no difference between patient and control males in liver cirrhosis of viral etiology. The BMD in men with cirrhosis might be maintained at a higher level compared to women as a consequence of the lack of estrogen inactivation secondary to the underlying liver disease $\mathrm{e}^{(7,28,33,40)}$

It has been reported that patients with alcoholic cirrhosis have particularly low $\mathrm{BMD}^{(30)}$. The association between alcohol abuse and osteoporosis might be explained by a combination of direct effects of alcohol on bone, liver dysfunction, poor diet, lack of sunlight, and hypogonadism ${ }^{(26,32)}$. Conversely, modest use of alcohol has been associated with a protection against osteoporosis ${ }^{(21)}$. We found no difference in BMD between alcoholic and nonalcoholic etiologies of liver disease. Our results are in agreement with those of DIAMOND et al. ${ }^{(8)}$ where the disease etiology itself was not a risk factor for osteopenic bone disease. Therefore, clinicians should maintain a high index of suspicion of osteopenia in all patients with chronic liver diseases regardless of etiology.

Our data support the findings of other series that describe an increase in prevalence and severity of osteoporosis with the progression of liver dysfunction ${ }^{(1,5,30,38)}$. Other authors have also reported a correlation between albumin and $\mathrm{BMD}^{(28)}$. TSUNEOKA et al. ${ }^{(38)}$ found osteoporosis in $20 \%$ of patients with chronic hepatitis and in $40 \%$ of patients with cirrhosis. Osteopenic bone disease in patients with PSC seems to increase as the liver disease advances ${ }^{(1)}$. A significant decrease in bone mass, particularly at the lumbar spine, is seen in patients with decompensated cirrhosis ${ }^{(30)}$. Liver dysfunction enhances bone loss and this loss is additive to that experienced as a result of aging and gender.

It has been established that osteoporosis, not osteomalacia, is the main metabolic bone disease in patients with liver diseases ${ }^{(3,8,37)}$. We found that serum calcium levels, but not corrected calcium levels, 
significantly decreased with the progression of the liver dysfunction. A reduction in the serum concentration of carrier protein (albumin) probably played a major role in the low serum calcium levels. These findings might suggest that the patients' dietary intakes of calcium or vitamin $\mathrm{D}$ were adequate and that osteoporosis was the major pathophysiological component in these patients. This is in consonance with the growing evidence that low bone mass is not related to abnormalities in vitamin D metabolism in liver diseases, but it still requires further research. DUARTE et al. ${ }^{(9)}$ studying Brazilian patients with chronic viral liver disease found no evidence of vitamin D deficiency. Unfortunately we do not routinely measure vitamin D and PTH levels but we agree that it would be interesting in order to clarify the major component of low BMD in these patients.

Post-menopausal status, aging and severe hepatic dysfunction clearly seem to be associated with an increased risk for low BMD in these patients. The lowest BMD was seen in women, aged more than 50 years and Child's C class. A patient's bone mass is the net result of these factors and the relative importance of each may vary from one individual to another. These attributes, however, are so broad that they provide relatively little help in identifying patients at high risk of developing low BMD. Similar to BONKOVSKI et al. ${ }^{(3)}$ we found that laboratory variables routinely determined in patients with liver disease were not useful in predicting low BMD. We do not measure routine indicators of bone turnover in our patients, but they have shown to be of limited value as predictors of osteopenia in chronic liver disease by other authors ${ }^{(3,30,31)}$. In an individual subject the only reliable means of detecting low BMD is bone densitometry, a direct and noninvasive measurement. With the improvements in techniques and reduction in cost, we recommend that all patients with liver cirrhosis should undergo at least one baseline bone density measurement through DEXA.
One of the limitations of this study is the lack of standardized reference data, perhaps on a geographical basis. Although the WHO criteria represent an important step in describing and characterizing osteopenia and osteoporosis, the applicability of these criteria to groups other than the ones used to obtain them is not certain. It should also be noted that, in any study, the absolute BMD values reported are densitometer-specific and can not be accurately compared with BMD results from other DEXA instruments without a conversion factor $^{(27)}$.

It remains to be determined whether low BMD can be satisfactory reversed in patients with liver diseases and if its treatment will decrease the cost, morbidity and mortality associated with osteoporotic fractures. Despite the fact that no effective therapy of proven benefit for osteoporosis in patients with liver diseases exists, it seems reasonable to maximize general measures such as adequate calcium and vitamin D intake, physical activities and to control other minor risk factors such as smoking. Finally, liver transplantation might have the potential to improve or stabilize osteopenic bone disease in a long-term.

In summary, low BMD is highly prevalent in NCC. There is a significant loss in bone mass associated with aging, female gender in post-menopausal status and advanced liver dysfunction. No standard laboratory tests reliably predicts low BMD. Further studies are needed to determine whether modifying risk factors and identifying "high-risk" patients who may benefit from preventive treatments in a cost-effective manner would reduce incidence of osteoporosis and the healthcare burden of associated fractures.

\section{ACKNOWLEDGMENTS}

The authors are gratefully indebted to Dr. Michael Charlton and Dr. J. Eillen Hay for their helpful review of the manuscript.

Figueiredo FAF, Brandão C, Perez RM, Barbosa WF, Kondo M. Diminuição da densidade mineral óssea na cirrose não-colestática: prevalência, fatores preditivos e gravidade. Arq Gastroenterol 2003;40(3):152-158

RESUMO - Racional - Existe associação entre doença óssea metabólica e doença hepática colestática. Contudo, a associação com cirrose não-colestática ainda é pouco conhecida. Objetivos - Determinar a prevalência e a gravidade da perda de densidade mineral óssea na cirrose não-colestática e investigar fatores preditivos do seu diagnóstico. Métodos - Oitenta e nove pacientes e 20 controles foram estudados de março a setembro de 1998. Todos foram submetidos a exames laboratoriais e densitometria óssea da coluna lombar e do colo do fêmur. Resultados - A massa óssea estava significativamente reduzida em ambos os sítios nos pacientes quando comparado aos controles. A prevalência da perda de massa óssea na cirrose não-colestática, de acordo com os critérios da Organização Mundial da Saúde, foi de $78 \%$ na coluna lombar e $71 \%$ no colo do fêmur. A massa óssea diminuiu significativamente com a idade em ambos os sítios, especialmente em pacientes acima de 50 anos. Pacientes mulheres pós-menopausa tinham massa óssea significativamente menor do que pacientes mulheres pré-menopausa e homens em ambos os sítios. Não houve diferença significativa na massa óssea entre as etiologias nãocolestáticas. A massa óssea da coluna lombar diminuiu significativamente com a progressão da disfunção hepática. Nenhuma variável bioquímica foi associada com a perda da massa óssea. Conclusões - A perda de massa óssea foi freqüente em pacientes com cirrose não-colestática. Pacientes idosos, do sexo feminino na pós-menopausa e com disfunção hepática grave apresentaram doença óssea mais avançada. Os exames laboratoriais rotineiramente dosados nos pacientes com doença hepática não puderam predizer com segurança a presença de redução na massa óssea.

DESCRITORES - Densidade óssea. Osteopatias metabólicas. Cirrose hepática. 


\section{REFERENCES}

1. Angulo P, Therneau TM, Jorgensen A, DeSotel CK, Egan KS, Dickson ER, Hay $\mathrm{JE}$, Lindor KD. Bone disease in patients with primary sclerosing cholangitis: prevalence, severity and prediction of progression. J Hepatol 1998;29:729-35.

2. Becker U, Almdal T, Christensen E, Gluud C, Farholt S, Bennett P, Svenstrup B, Hardt $F$. Sex hormones in postmenopausal women with primary biliary cirrhosis. Hepatology 1991;13:865-9.

3. Bonkovsky HL, Hawkins M, Steinberg K, Hersh T, Galambos JT, Henderson JM, Millikan WJ, Galloway JR. Prevalence and prediction of osteopenia in chronic liver disease. Hepatology 1990;12:273-80.

4. Compston JE. Hepatic osteodystrophy: vitamin D metabolism in patients with liver disease. Gut 1986;27:1073-90.

5. Corazza GR, Trevisani F, Di Stefano M, De Notariis S, Veneto G, Cecchetti L, Minguzzi L, Gasbarrini G, Bernardi M. Early increase of bone resorption in patients with liver cirrhosis secondary to viral hepatitis. Dig Dis Sci 2000;45:1392-9.

6. Cullum ID, Ell PJ, Ryder JP. X-ray dual-photon absorptiometry: a new method for the measurement of bone density. Br J Radiol 1989;62:587-92.

7. De Besi L, Zucchetta P, Zotti S, Mastrogiacomo I. Sex hormones and sex hormone binding globulin in males with compensated and decompensated cirrhosis of the liver. Acta Endocrinol (Copenh) 1989;120:271-6.

8. Diamond T, Stiel D, Lunzer M, Wilkinson M, Roche J, Posen S. Osteoporosis and skeletal fractures in chronic liver disease. Gut 1990;31:82-7.

9. Duarte MP, Farias ML, Coelho HS, Mendonca LM, Stabnov LM, do Carmo d Oliveira M, Lamy RA, Oliveira DS. Calcium-parathyroid hormone-vitamin D axis and metabolic bone disease in chronic viral liver disease. J Gastroenterol Hepatol 2001;16:1022-7.

10. Eastell R, Dickson ER, Hodgson SF, Wiesner RH, Porayko MK, Wahner HW, Cedel SL, Riggs BL, Krom RA. Rates of vertebral bone loss before and after liver transplantation in women with primary biliary cirrhosis. Hepatology 1991;14:296-300.

11. Feldman H, Wolfson A. Disorders of calcium and magnesium metabolism. In: Wolfson AB, editor. Endocrine and metabolic emergencies. New York: Churchill Livingstone; 1990. p.45.

12. Floreani A, Mega A, Tizian L, Burra P, Boccagni P, Baldo V, Fagiuoli S, Naccarato R, Luisetto $\mathrm{G}$. Bone metabolism and gonad function in male patients undergoing liver transplantation: a two-year longitudinal study. Osteoporos Int 2001;12:749-54.

13. Gavaler JS, van Thiel DH. Hormonal status of postmenopausal women with alcohol-induced cirrhosis: further findings and a review of the literature. Hepatology 1992;16:312-9.

14. Grotz W, Rump L, Schollmeyer P. Osteoporosis in transplant recipients. Recommendations for avoidance and therapy. Biodrugs 1997;7:433-40.

15. Guanabens N, Pares A, Marinoso L, Brancos MA, Piera C, Serrano S, Rivera F, Rodes J. Factors influencing the development of metabolic bone disease in primary biliary cirrhosis. Am J Gastroenterol 1990;85:1356-62.

16. Guichelaar MM, Malinchoc M, Sibonga J, Clarke BL, Hay JE. Bone metabolism in advanced cholestatic liver disease: analysis by bone histomorphometry. Hepatology 2002;36:895-903.

17. Hay JE. Bone disease in liver transplant recipients. Gastroenterol Clin North Am 1993;22:337-49.

18. Hay JE, Lindor KD, Wiesner RH, Dickson ER, Krom RA, LaRusso NF. The metabolic bone disease of primary sclerosing cholangitis. Hepatology 1991;14:257-61.

19. Heaf JG. Hepatic osteodystrophy. Scand J Gastroenterol 1985;20:1035-40.
20. Hodgson SF, Dickson ER, Wahner HW, Johnson KA, Mann KG, Riggs BL. Bone loss and reduced osteoblast function in primary biliary cirrhosis. Ann Intern Med 1985;103:855-60.

21. Holbrook TL, Barrett-Connor E. A prospective study of alcohol consumption and bone mineral density. Br Med J 1993;306:1506-9.

22. Idilman R, de Maria N, Uzunalimoglu O, van Thiel DH. Hepatic osteodystrophy: a review. Hepatogastroenterology 1997;44:574-81.

23. Kalef-Ezra JA, Merkouropoulos MH, Challa A, Hatzikonstantinou J, Karantana $\mathrm{AH}$, Tsianos EV. Amount and composition of bone minerals in chronic liver disease. Dig Dis Sci 1996;41:1008-13.

24. Kanis JA, Melton LJ 3rd, Christiansen C, Johnston CC, Khaltaev N. The diagnosis of osteoporosis. J Bone Miner Res 1994;9:1137-41.

25. Keen R, Spector T. Epidemiology of osteoporosis. In: Geusens P. ed Osteoporosis in clinical practice. A practical guide for diagnosis and treatment London: Springer-Verlag; 1998. p.17-21.

26. Laitinen K, Valimaki M. Alcohol and bone. Calcif Tissue Int 1991;49:S70-3.

27. Looker AC, Orwoll ES, Johnston CC Jr, Lindsay RL, Wahner HW, Dunn WL, Calvo MS, Harris TB, Heyse SP. Prevalence of low femoral bone density in older US adults from NHANES III. J Bone Miner Res 1997;12:1761-8.

28. Masaki K, Shiomi S, Kuroki T, Tanaka T, Monna T, Ochi H. Longitudinal changes of bone mineral content with age in patients with cirrhosis of the liver. J Gastroenterol 1998;33:236-40.

29. Melton LJ, 3rd, Eddy DM, Johnston CC Jr. Screening for osteoporosis. Ann Intern Med 1990;112:516-28

30. Monegal A, Navasa M, Guanabens N, Peris P, Pons F, Martinez de Osaba MJ, Rimola A, Rodes J, Munoz-Gomez J. Osteoporosis and bone mineral metabolism disorders in cirrhotic patients referred for orthotopic liver transplantation. Calcif Tissue Int 1997;60:148-54.

31. Pares A, Guanabens N, Alvarez L, Martinez de Osaba MJ, Monegal A, Peris P. Collagen-related markers of bone turnover in primary biliary cirrhosis [abstract] Hepatology 1997;26:402A

32. Peris P, Pares A, Guanabens N, Pons F, Martinez de Osaba MJ, Caballeria J, Rodes J, Munoz-Gomez J. Reduced spinal and femoral bone mass and deranged bone mineral metabolism in chronic alcoholics. Alcohol Alcohol 1992;27:619-25.

33. Pignata S, Daniele B, Galati M G, Esposito G, Vallone P, Fiore F, Ricchi P, Pergola M. Oestradiol and testosterone blood levels in patients with viral cirrhosis and hepatocellular carcinoma. Eur J Gastroenterol Hepatol 1997;9:283-6.

34. Porayko MK, Wiesner RH, Hay JE, Krom RA, Dickson ER, Beaver S, Schwerman L. Bone disease in liver transplant recipients: incidence, timing, and risk factors. Transplant Proc 1991;23:1462-5.

35. Pugh RN, Murray-Lyon IM, Dawson JL, Pietroni MC, Williams R. Transection of the oesophagus for bleeding oesophageal varices. Br J Surg 1973;60:646-9.

36. Stellon AJ, Webb A, Compston JE. Bone histomorphometry and structure in corticosteroid treated chronic active hepatitis. Gut 1988;29:378-84.

37. Stellon AJ, Webb A, Compston J, Williams R. Lack of osteomalacia in chronic cholestatic liver disease. Bone 1986;7:181-5.

38. Tsuneoka K, Tameda Y, Takase K, Nakano T. Osteodystrophy in patients with chronic hepatitis and liver cirrhosis. J Gastroenterol 1996;31:669-78.

39. Vernejoul M. Bone structure and function. In: Geusens P, editor. Osteoporosis in practice clinical. A practical guide for diagnosis and treatment. London: Springer-Verlag; 1998. p.1-4

40. Wang YJ, Wu JC, Lee SD, Tsai YT, Lo KJ. Gonadal dysfunction and changes in sex hormones in postnecrotic cirrhotic men: a matched study with alcoholic cirrhotic men. Hepatogastroenterology 1991;38:531-4.

Recebido em 6/11/2002 Aprovado em 17/3/2003 